University of Nebraska - Lincoln

DigitalCommons@University of Nebraska - Lincoln

6-1999

\title{
Molybdenum Accumulation in Cariaco Basin Sediment Over the Past 24 k.y.: A Record of Water-Column Anoxia and Climate
}

Walter E. Dean

U.S. Geological Survey, MS 980, Federal Center, Denver, Colorado 80225, USA

David Z. Piper

U.S. Geological Survey, MS 902, 345 Middlefield Road, Menlo Park, California 94025, USA

Larry C. Peterson

University of Miami

Follow this and additional works at: https://digitalcommons.unl.edu/usgsstaffpub

Part of the Earth Sciences Commons

Dean, Walter E.; Piper, David Z.; and Peterson, Larry C., "Molybdenum Accumulation in Cariaco Basin Sediment Over the Past 24 k.y.: A Record of Water-Column Anoxia and Climate" (1999). USGS Staff -Published Research. 298.

https://digitalcommons.unl.edu/usgsstaffpub/298

This Article is brought to you for free and open access by the US Geological Survey at DigitalCommons@University of Nebraska - Lincoln. It has been accepted for inclusion in USGS Staff -- Published Research by an authorized administrator of DigitalCommons@University of Nebraska - Lincoln. 


\title{
Molybdenum accumulation in Cariaco basin sediment over the past 24 k.y.: A record of water-column anoxia and climate
}

\author{
Walter E. Dean \\ U.S. Geological Survey, MS 980, Federal Center, Denver, Colorado 80225, USA \\ David Z. Piper \\ U.S. Geological Survey, MS 902, 345 Middlefield Road, Menlo Park, California 94025, USA \\ Larry C. Peterson \\ Rosenstiel School of Marine and Atmospheric Science, University of Miami, Miami, Florida 33149, USA
}

\begin{abstract}
Molybdenum (Mo) concentrations in a sediment core from the Cariaco basin on the Venezuelan continental shelf can be partitioned between a marine fraction and a terrigenous fraction. The accumulation rate of the marine fraction of Mo increased abruptly 15000 calendar years ago (15 ka), from $<0.5 \mu \mathrm{g}^{\bullet} \mathrm{cm}^{-2} \cdot \mathrm{yr}^{-1}$ to $>4 \mu \mathrm{g}^{\bullet} \mathrm{cm}^{-2} \cdot \mathrm{yr}^{-1}$, and then decreased abruptly at $9 \mathrm{ka}$. The accumulation rate remained high throughout this $6 \mathrm{k} . \mathrm{y}$. period, but exhibited maxima at 15-14 and $12.5 \mathrm{ka}$, corresponding in time to meltwater pulse IA into the Gulf of Mexico and the onset of the Younger Dryas cold event, respectively. The marine fraction of Mo is interpreted in terms of redox conditions of bottom water, as dictated by both the flux of settling organic matter and bottom-water residence time. Correspondence between geochemical extremes in this core with changes in sea level and global climate demonstrates the high degree to which this ocean-margin basin has responded to the paleoceanographic regime throughout the past $24 \mathrm{k.y}$.
\end{abstract}

\section{INTRODUCTION}

The Cariaco basin on the Venezuelan continental shelf consists of two basins, each greater than $1300 \mathrm{~m}$ deep, separated by a saddle (Fig. 1). The basin is separated from deep water of the Caribbean Sea by a 146-m-deep sill. Water entering the basin at the sill depth is nutrient enriched and oxygen depleted (about half of the dissolved oxygen content of surface Caribbean waters) (Peterson et al., 1991). The combination of high productivity, restricted circulation, and oxygen depletion leads to sulfate-reducing conditions in water below about $300 \mathrm{~m}$ (Richards and Vaccaro, 1956).

The present climate in the region is highly seasonal, controlled by the position of the Intertropical convergence zone. During winter, the zone is south of the equator and strong northeasterly trade winds produce intense upwelling and high organic productivity. The siliceous remains of diatoms and silicoflagellates and calcareous remains of foraminifera and nannoplankton produced during this upwelling period are preserved in the sediments as light colored laminations (Hughen et al., 1996). By early summer, the Intertropical convergence zone is north of the equator, the northeasterly trade winds weaken, and upwelling is much reduced. The summer is also the rainy season, which produces an increase in runoff and, consequently, increased influx of terrigenous material that forms dark laminations. These couplets of light and dark annual laminae or varves characterize the sediment that accumulated in the Cariaco basin over most of the past $12.6{ }^{14} \mathrm{C}$ k.y. (15000 calendar yr). Their preservation and the absence of a benthic microfauna are taken to imply the continuous presence of anoxic bottom waters (Peterson et al., 1991).

Core PL07-39PC was collected on the saddle separating the two subbasins at $790 \mathrm{~m}$ water depth (Fig. 1). The age model for this core is based on 29 AMS (accelerator mass spectrometer) ${ }^{14} \mathrm{C}$ dates of hand-picked samples of the planktonic foraminifer Globigerina bulloides, corrected for radiocarbon differences between the atmosphere and local surface water by subtracting $420 \mathrm{yr}$ from the measured radiocarbon age (Lin et al., 1997). Hughen et al. (1998) used a varve chronology to calibrate the corrected radiocarbon dates spanning $12.6-7.6{ }^{14} \mathrm{C} \mathrm{ka}$, tree rings to calibrate radiocarbon dates after $7.6{ }^{14} \mathrm{C} \mathrm{ka}$, and correlation of gray-scale measurements in cores from this basin with accumulation rates in the GISP2 ice core to calibrate radiocarbon dates before $12.6{ }^{14} \mathrm{C} \mathrm{ka}$. Sedimentation rates derived from this age model were combined with dry bulk-density measurements on each of our 5-cmspaced samples to calculate accumulation rates. Calendar-year ages (ka) from the Hughen et al. (1998) age model are used in this paper.

Although variable, sediment-accumulation rates are fast enough ( 30 to $>100 \mathrm{~cm} / \mathrm{k}$.y.) to provide resolution of oceanographic events of a few hundred years duration through the use of samples

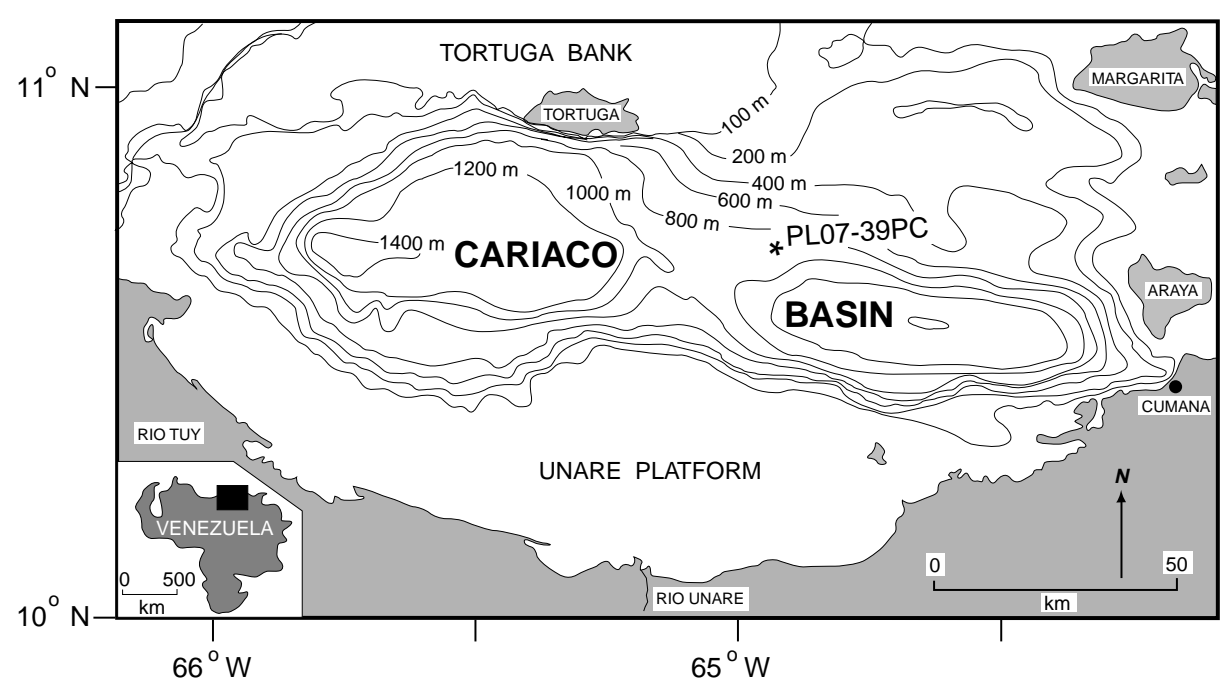

Figure 1. Bathymetry of northern continental margin of Venezuela showing location of core PL07-39PC (modified from Peterson et al., 1991). 
that integrate a few millimeters to a few centimeters of sediment, but not so fast as to dilute the marine minor element signature. The sediment is faintly laminated from the sediment-water interface to about $300 \mathrm{~cm}$. Laminae are more distinctly defined and thicker from 600 to $300 \mathrm{~cm}$ (Fig. 2); the sediment is bioturbated below the laminated unit. Peterson et al. (1991) interpreted the lithologic change occurring between the bioturbated and laminated units $\left(12.6{ }^{14} \mathrm{C} \mathrm{ka}\right.$, or $\left.15 \mathrm{ka}\right)$ as reflecting initiation of anoxia in the bottom water, which has continued to the present. Changes in the faunal and stable isotope composition of planktonic foraminifera correspond to this lithologic change. They were interpreted as marking the onset of strong upwelling, increased primary productivity, and rising sea level that established more open exchange with the Caribbean Sea (Peterson et al., 1991; Lin et al., 1997).

\section{SOURCES OF TRACE ELEMENTS IN ANOXIC SEDIMENTS}

In this study we examined the trace element composition of piston core PL07-39PC to (1) distinguish the marine and terrigenous supplies of elements to the sediment and (2) to employ the distribution of the marine component to determine the paleoceanographic history of redox conditions in the bottom water.

Trace elements that rain onto the sea floor have two sources, detrital clastic debris (detritus) and seawater. The seawater-derived fraction also has two components: (1) that which is incorporated into the hard and soft parts of marine organisms and (2) that which is removed from the dissolved elemental load of seawater by some inorganic process. The detrital source can be evaluated by relations between the concentration of aluminum (expressed as $\mathrm{Al}_{2} \mathrm{O}_{3}$ ), a dominantly lithogenic element, and the concentrations of other elements. For example, concentrations of $\mathrm{Co}, \mathrm{Ga}$, and $\mathrm{Th}$ in core PL07-39PC, when plotted against those of $\mathrm{Al}_{2} \mathrm{O}_{3}$ (Fig. 3A), fall along lines that are close to the trends for the world shale average (Wedepohl, 1969-1978) and that pass through the origin. Because $\mathrm{Al}$ is derived entirely from detritus, essentially all of the $\mathrm{Co}, \mathrm{Ga}$, and $\mathrm{Th}$ also are contributed by detritus. Other major, minor, and trace elements that are highly correlated with $\mathrm{Al}_{2} \mathrm{O}_{3}$ include Ti, $\mathrm{Mg}, \mathrm{Na}, \mathrm{K}, \mathrm{Ce}, \mathrm{La}, \mathrm{Nb}$, and $\mathrm{Nd}$. How-

\section{$\mathrm{Al}_{2} \mathrm{O}_{3}(\%) \mathrm{Mo}(\mathrm{ppm})$}

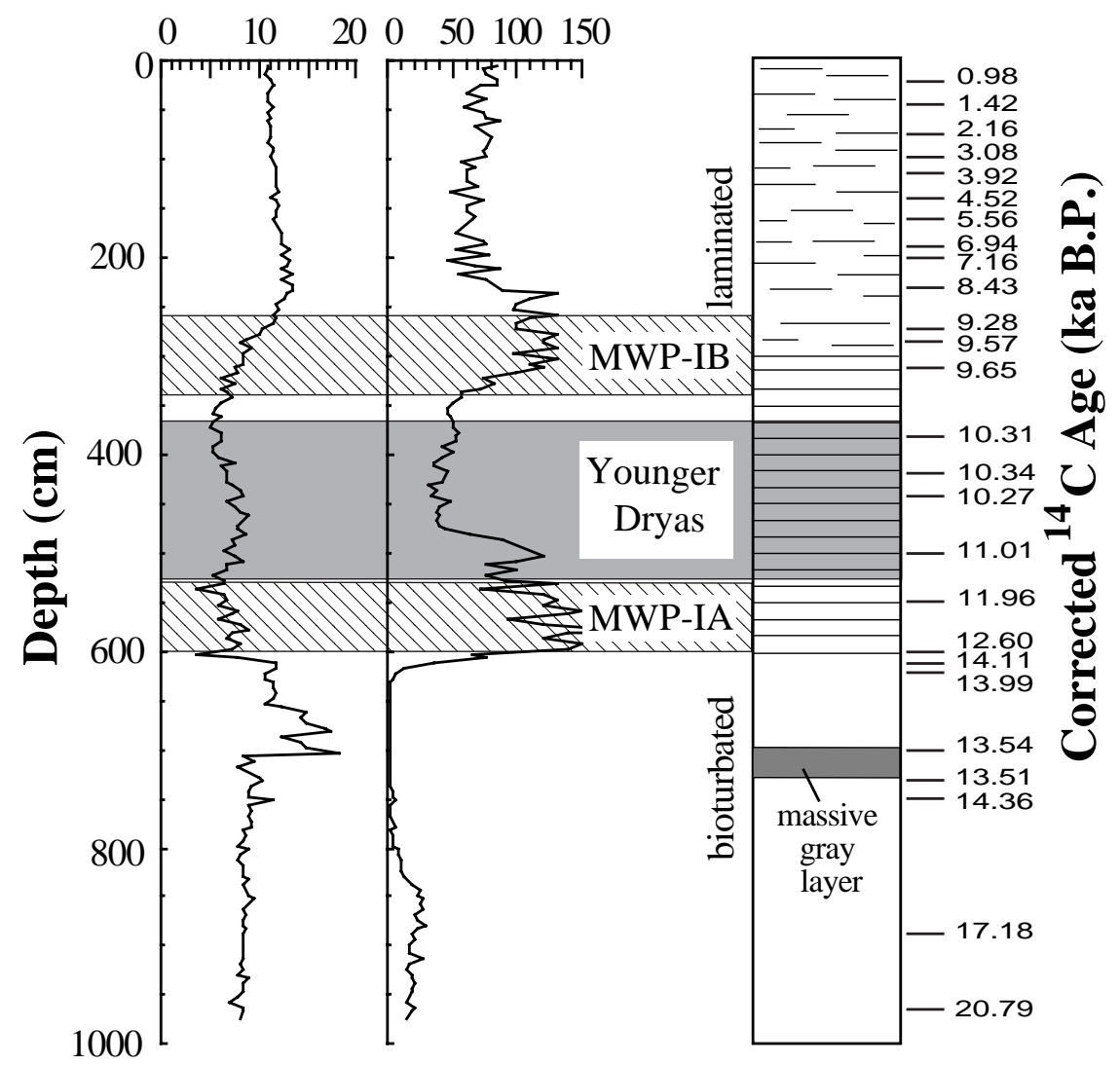

Figure 2. Variations in concentrations of $\mathrm{Al}_{2} \mathrm{O}_{3}$ and Mo with depth in core PL07-39PC. Sediment is faintly laminated to $300 \mathrm{~cm}$, distinctly laminated between 300 and $600 \mathrm{~cm}$, and bioturbated below $600 \mathrm{~cm}$. There is massive, fine-grained gray layer at $700 \mathrm{~cm}$ (Lin et al., 1997). Radiocarbon ages are corrected accelerator mass spectrometer ${ }^{14} \mathrm{C}$ ages, as reported by Lin et al. (1997). Core is divided into three sections: Younger Dryas cold event (shaded) and meltwater pulses IA and IB (diagonal-rule pattern; Fairbanks, 1989). ever, Mo shows no correlation with $\mathrm{Al}_{2} \mathrm{O}_{3}$ and concentrations are much higher than in the world shale average (Figs. 2 and 3B). This type of relationship suggests that Mo must have a significant seawater source.

Contributions of trace elements contributed by organic matter can only be estimated by comparing trace element concentrations in sediment with those in organic matter (plankton) from the modern ocean (Collier and Edmond, 1984; Brumsack, 1986; Piper, 1994). The data for core PL07-39PC (Fig. 3B) show that Mo concentrations (to $150 \mathrm{ppm}$ ) are considerably greater than can be explained from detritus or plankton (both contain 2 ppm Mo). We agree with Brumsack (1986) that the excess of most trace elements in upwelling sediments can be explained by a plankton source, but that excess Mo must be derived from seawater, either from sulfidic bottom waters during deposition (e.g., Piper, 1994) or by diffusion of Mo into the sediments (e.g., Emerson and Huested, 1991; Crusius et al., 1996).

Several trace elements, such as Se, Re, U, V, $\mathrm{Ni}, \mathrm{Cd}$, and Mo, are concentrated in sediments in basins where sulfate reduction occurs in bottom waters (Jacobs et al., 1987; Emerson and Huested, 1991; Crusius et al., 1996). We focus on Mo in our study because it is the diagnostic element in sediments that accumulate under seawater sulfate-reducing conditions. The concentration of Mo in the world shale average is 2 ppm, and we assume that this is a good estimate of the Mo concentration in the detrital fraction in Cariaco basin sediment. Thus, the contribution of detrital Mo to the total Mo inventory is obtained by multiplying the $\mathrm{Al}_{2} \mathrm{O}_{3}$ content of a sample by $1.3 \times 10^{-5}$, the world shale average $\mathrm{Mo} / \mathrm{Al}_{2} \mathrm{O}_{3}$ ratio. The residual Mo content $(>95 \%$ in most samples) can then be assigned to a marine origin, i.e., Mo that accumulated as a seawater precipitate and adsorbed onto particulate organic matter.

The present removal rate of Mo from the sulfate-reducing part of the water column in the Cariaco basin (Emerson and Huested, 1991) also supports the interpretation of Mo accumulation predominantly from bottom water. The removal rate is determined by the initial concentration of Mo in seawater (10 ppb; Bruland, 1983), its lower concentration in bottom water of the basin (85\% that of surface water; Emerson and Huested, 1991), the thickness of the sulfatereducing part of the water column $(1000 \mathrm{~m}$; Emerson and Huested, 1991), and the residence time of the bottom water (100-200 yr; Deuser, 1973). These measurements give a calculated rate of Mo removal from the water column of $0.7-1.4 \mu \mathrm{g} \cdot \mathrm{cm}^{-2} \cdot \mathrm{yr}^{-1}$, the same as its accumulation rate over the past 500-1000 yr of 0.6$1.2 \mu \mathrm{g} \cdot \mathrm{cm}^{-2} \cdot \mathrm{yr}^{-1}$ (Fig. 4). Thus, the total marine fraction of Mo in the sediment can be attributed to removal from bottom water. 


\section{Mo ACCUMULATION RATE}

On the basis of Mo accumulation over the past 24 k.y. (Fig. 4), the core can be divided into the following three sections: (1) 24-15 ka, (2) 15-9 ka, and (3) 9-0 ka, which are approximately the same as the divisions based on plankton distributions and lithology (Peterson et al., 1991). The oldest section has lower marine Mo accumulation rates than the rest of the core, but has slightly elevated values between 23 and $18 \mathrm{ka}$. The section between 15 and 9 ka has high but variable marine Mo accumulation rates, and three welldefined maxima. The maximum between 15 and 14 ka corresponds in time to the abrupt start of deglaciation as marked by meltwater pulse IA (MWP-IA; Fairbanks, 1989), the first major input of meltwater from the Laurentide ice sheet into the Gulf of Mexico through the Mississippi River. The maximum at 12.5 ka corresponds in time to the onset of the Younger Dryas cold event (Fairbanks, 1990). Several lesser maxima in marine Mo accumulation rates occurred later within the Younger Dryas interval (Fig. 4). The broad maximum in marine Mo accumulation rate between 11 and $9 \mathrm{ka}$ does not coincide in time with meltwater pulse IB (MWP-IB; Fig. 4), but rather follows it. The accumulation rate of Mo from $9 \mathrm{ka}$ to the present appears to be uniform, compared to variations between 15 and $9 \mathrm{ka}$.

The accumulation rate of detrital Mo simply reflects the accumulation rate of the detritus; the accumulation rate of any element that resides almost entirely in detritus (e.g., Al, Co, Ga, or Th, discussed earlier) would have the same shape as the profile for detrital Mo. Between 9 and $0 \mathrm{ka}$ the accumulation rate of detrital Mo closely parallels that of marine Mo (Fig. 4). However, this relation is not maintained throughout older sections of the core. For example, the lowest accumulation rate of marine Mo at 16 ka corresponds to the highest accumulation rate of detrital Mo. Thus, the close similarity between the two Mo accumulation rates from $9 \mathrm{ka}$ to the present (Fig. 4) is not an artifact of our partitioning calculation.

\section{Mo, PRODUCTIVITY, AND ANOXIA}

How might variations in the accumulation rate of marine Mo after $15 \mathrm{ka}$ be related to changes in primary productivity, as proposed by Peterson et al. (1991) to explain the foraminiferal record, when the accumulation of biogenic debris must represent a small part of the total input of Mo to the sediment? Primary productivity determines the flux of organic matter that settles through the water column. This, in turn, drives the rate of bacterial respiration in the water column, i.e., the biological oxygen demand, and the buildup of $\mathrm{H}_{2} \mathrm{~S}$ in the bottom water. The influx of oxygencharged water into the basin opposes this buildup of $\mathrm{H}_{2} \mathrm{~S}$. Thus, primary productivity and bottomwater residence time are inextricably linked in the establishment of $\mathrm{H}_{2} \mathrm{~S}$ in the bottom water.
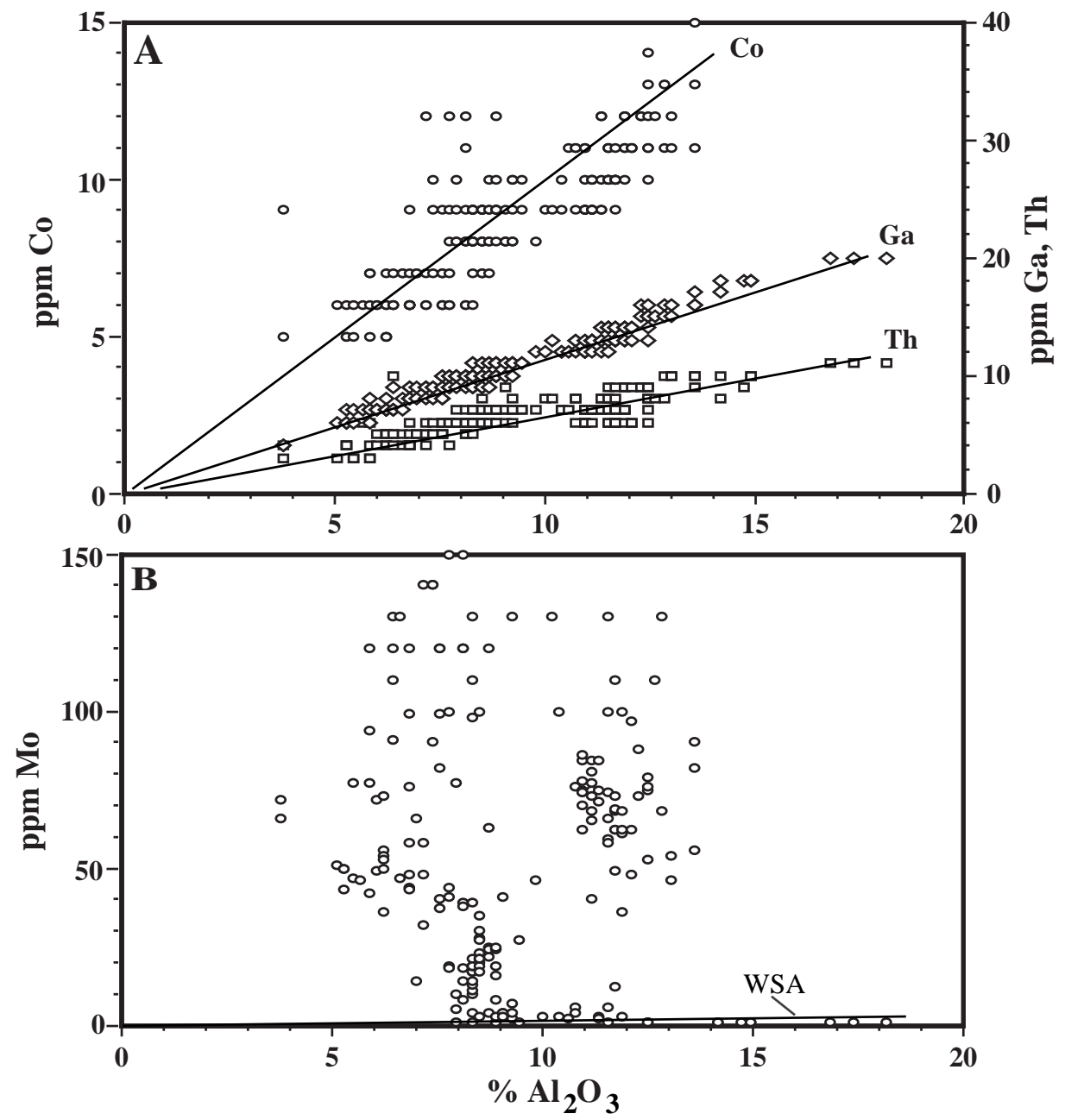

Figure 3. Relations between concentrations of $\mathrm{Al}_{2} \mathrm{O}_{3}$ and $(\mathrm{A}) \mathrm{Co}, \mathrm{Ga}$, and Th and (B) Mo in samples from core PL07-39PC. Solid lines through data for each element give element- $\mathrm{Al}_{2} \mathrm{O}_{3}$ relations in world shale average (WSA; Wedepohl, 1969-1978).

Emerson and Huested (1991) presented both the $\mathrm{H}_{2} \mathrm{~S}$ concentrations and rates of Mo removal in bottom waters of several marine basins. A positive correlation between these two variables (Piper and Isaacs, 1995) suggests that they are also linked, although there is considerable debate as to the actual mechanism of Mo removal from bottom waters (precipitation as a sulfide, adsorption onto settling particulate debris, or diffusion across the benthic boundary layer). The relation between Mo removal and bottom-water $\mathrm{H}_{2} \mathrm{~S}$ concentration does not address directly the actual mechanism whereby Mo is removed from the bottom water, but it does allow the removal of Mo from bottom water to be related to the balance between the two master variables - primary productivity in the photic zone and advection of bottom water into the basin

The very low concentration of Mo between 800 and $600 \mathrm{~cm}$ (Fig. 2; 18-15 ka in Fig. 4) suggests that bottom-water ventilation was strong enough (i.e., residence time brief enough), and/or primary productivity weak enough, to prevent formation of $\mathrm{H}_{2} \mathrm{~S}$ in the bottom water. Both may have contributed to oxic conditions in the bottom water, a condition further required to support the preserved benthic fauna (Peterson et al., 1991). A lower sea level during the last glacial interval (24-15 ka) meant a shallow sill depth $(\sim 25 \mathrm{~m})$ for the Cariaco basin, requiring that water entering the basin would have been well oxygenated but nutrient depleted. The planktonic foraminiferal record of sediment deposited between 18 and 15 ka (Peterson et al., 1991) confirms low productivity for the nearly totally isolated Cariaco basin. The oxygen demand in bottom water prior to $18 \mathrm{ka}$ is less clear, but elevated Mo values (Fig. 4) and low abundance of benthic foraminifera (Peterson et al., 1991) both suggest oxygen depletion prior to $18 \mathrm{ka}$.

The abrupt increase in Mo accumulation rate at $15 \mathrm{ka}$ (Fig. 4), together with the sudden preservation of well-laminated sediments and the elimination of benthic foraminifera (Peterson et al., 1991), are all indicative of a rapid return to sulfate-reducing conditions in the bottom water, even more intense than prior to $18 \mathrm{ka}$. The rapid rise in sea level that accompanied MWP-IA (Fairbanks, 1989) would have reconnected the northern margin of the basin with the open 
Lithology

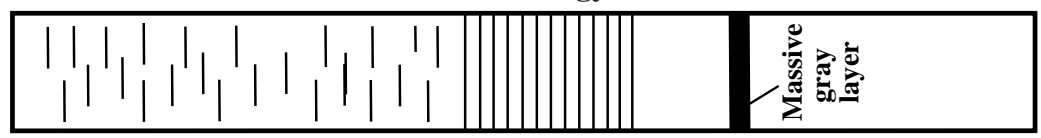

faintly laminated $\begin{aligned} & \text { distinctly bioturbated } \\ & \text { laminated }\end{aligned}$

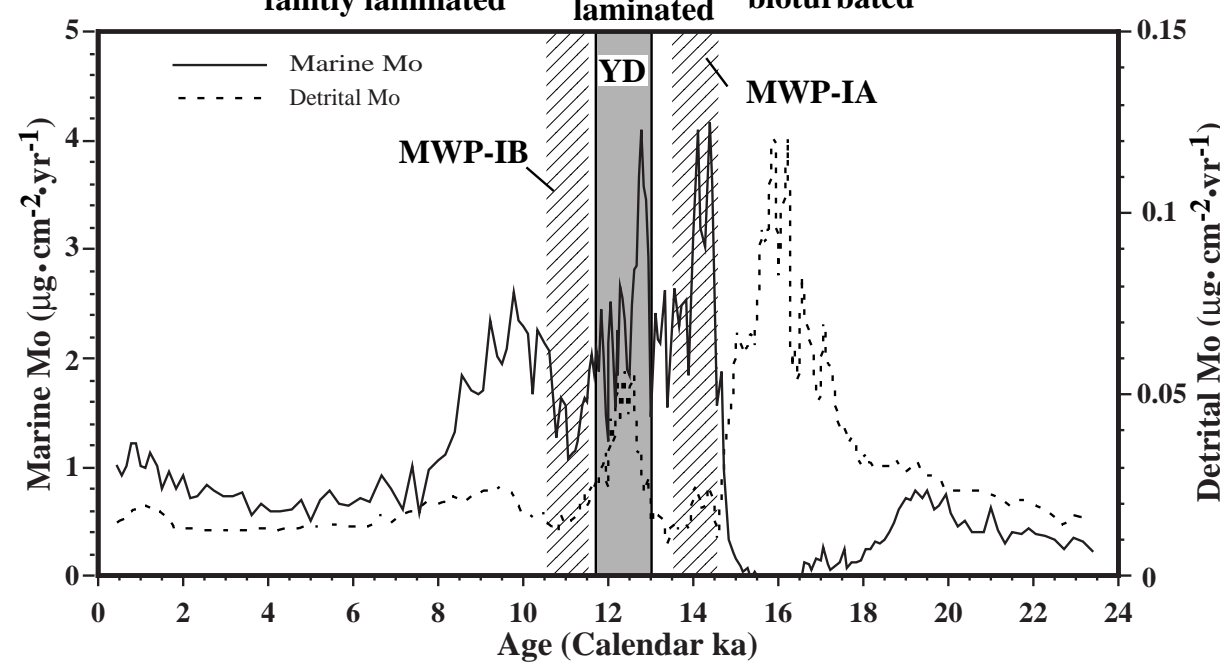

Figure 4. Accumulation rates of detrital and marine fractions of Mo vs. age. Shaded area represents Younger Dryas (YD) cold event and areas with diagonal-rule pattern represent meltwater pulses (MWP) IA and IB (Fairbanks, 1989).

Caribbean Sea and possibly shifted the center of upwelling southward over the Cariaco basin. A reduction in bottom-water advection might have contributed to oxygen-depleted bottom water, but all primary-productivity proxy variables indicate that the Younger Dryas cold event was the time of highest productivity in the Cariaco basin over the past 24 k.y. Sediment deposited at this time contains an increased abundance of diatoms and the productivity-indicator foraminifera $G$. bulloides (Peterson et al., 1991). Accumulation rates of biogenic carbonate and silica were markedly higher (Peterson et al., 1995). Light colored varve laminae deposited during the Younger Dryas are also thicker, owing to an elevated flux of biogenic components (Hughen et al., 1996). The maxima in Mo accumulation rate corresponding to MWP-IA and MWP-IB, however, might reflect maxima in bottom-water residence time, or possibly reduction in $\mathrm{O}_{2}$ concentration of water entering over the sill from the Caribbean Sea. Lower sea level during the meltwater pulses than now (Fairbanks, 1989) would seem to discount this latter option. Although primary productivity and bottom-water residence time work together, we favor maxima in primary productivity that produced maxima in the flux of organic matter settling into the bottom water, rather than pulses in residence time. The current rate of organic-carbon production averages about 100$200 \mathrm{~g} \cdot \mathrm{m}^{-2} \cdot \mathrm{yr}^{-1}$ (Berger, 1989), but organic-carbon production rates of $700-1000 \mathrm{~g} \cdot \mathrm{m}^{-2} \cdot \mathrm{yr}^{-1}$ are common during the winter upwelling season, and rates as high as $2500 \mathrm{~g} \cdot \mathrm{m}^{-2} \cdot \mathrm{yr}^{-1}$ have been measured (Varela et al., 1997). We suggest that
Deuser, W. G., 1973, Cariaco Trench: Oxidation of organic matter and residence time of anoxic water: Nature, v. 242, p. 601-603.

Emerson, S. R., and Huested, S. S., 1991, Ocean anoxia and concentrations of molybdenum and vanadium in seawater: Marine Chemistry, v. 34, p. 177-196.

Fairbanks, R. G., 1989, A 17,000-year glacio-eustatic sea level record: Influence of glacial melting rates on the Younger Dryas event and deep-ocean circulation: Nature, v. 342, p. 637-641.

Fairbanks, R. G., 1990, The age and origin of the "Younger Dryas climate event" in Greenland ice cores: Paleoceanography, v. 5, p. 937-948.

Hughen, K. A., Overpeck, J. T., Peterson, L. C., and Trumbore, S., 1996, Rapid climate changes in the tropical Atlantic region during the last deglaciation: Nature, v. 380, p. 51-54.

Hughen, K. A., Overpeck, J. T., Lehman, S. R., Kashgarian, M., Southon, J., Peterson, L. C., Alley, R., and Sigman, D. M., 1998, Deglacial changes in ocean circulation from an extended radiocarbon calibration: Nature, v. 391, p. 65-68.

Jacobs, L., Emerson, S., and Huested, S. S., 1987, Trace metal chemistry in the Cariaco Trench: Deep-Sea Research, v. 34, p. 965-981.

Lin, H.-L., Peterson, L. C., Overpeck, J. T., Trumbore, S. E., and Murray, D. W., 1997, Late Quaternary climate change from $\delta^{18} \mathrm{O}$ records of multiple species of planktonic foraminifera: High-resolution records from the anoxic Cariaco basin, Venezuela: Paleoceanography, v. 12, p. 415-427.

Peterson, L. C., Overpeck, J. T., Kipp, N. G., and Imbrie, J., 1991, A high-resolution late Quaternary upwelling record from the anoxic Cariaco basin, Venezuela: Paleoceanography, v. 6, p. 99-119.

between 15 and $9 \mathrm{ka}$, such surges in primary productivity were the rule, rather than the exception, as they are today.

\section{ACKNOWLEDGMENTS}

This research was supported in part by the U.S. Geological Survey Global Change and Climate History Program (Dean) and U.S. Geological Survey Energy Program (Dean and Piper). Comments and suggestions by George Breit, Keith Kvenvolden, Tim Lyons, Rick Murray, Greg Ravizza, and George Smith greatly improved the paper.

\section{REFERENCES CITED}

Berger, W. H., 1989, Global maps of ocean productivity, in Berger, W. H., Smetacek, V. S., and Wefer, G., eds., Productivity of the ocean: Present and past: New York, Wiley, p. 429-455.

Bruland, K. W., 1983, Trace elements in seawater, in Riley, J. P., and Chester, R., eds., Chemical oceanography, Volume 8: London, Academic Press, p. 157-220.

Brumsack, H. J., 1986, The inorganic geochemistry of Cretaceous black shales (DSDP Leg 41) in comparison to modern upwelling sediments from the Gulf of California, in Summerhayes, C. P., and Shackleton, N. J., eds., North Atlantic paleoceanography: Geological Society [London] Special Publication 21, p. 447-462.

Collier, R., and Edmond, J., 1984, The trace element chemistry of marine biogenic particulate matter: Progresses in Oceanography, v. 13, p. 113-119.

Crusius, J., Calvert, S., Pedersen, T., and Sage, D., 1996, Rhenium and molybdenum enrichments in sediments as indicators of oxic, suboxic, and sulfidic conditions of deposition: Earth and Planetary Science Letters, v. 145, p. 65-78.
Peterson, L. C., Overpeck, J. T., and Murray, D. W, 1995, Anoxic basin records detailed climate history: Drill Bits (JOI/USSAC Newsletter), v. 8, p. 10-13.

Piper, D. Z., 1994, Seawater as the source of minor elements in black shales, phosphorites, and other sedimentary deposits: Chemical Geology, v. 14, p. 95-114.

Piper, D. Z., and Isaacs, C. M., 1995, Geochemistry of minor elements in the Monterey Formation, California; seawater chemistry of deposition: U.S. Geological Survey Professional Paper 1566, 41 p.

Richards, F. A., and Vaccaro, R. F., 1956, The Cariaco Trench, an anaerobic basin in the Caribbean Sea: Deep-Sea Research, v. 3, p. 214-228.

Varela, R., Capelo, J. C., Gutierrez, J., Muller-Karger, F., and Diaz-Ramos, J. R., 1997, Primary productivity in Cariaco basin waters: Eos (Transactions, American Geophysical Union), v. 78, p. F342.

Wedepohl, K. H., ed., 1969-1978, Handbook of geochemistry, Volumes I-IV: Berlin, Springer-Verlag.

Manuscript received December 15, 1998

Revised manuscript received March 5, 1999

Manuscript accepted March 15, 1999 